\title{
Exogenous supplementation of carbohydrases lowers serum insulin and cholesterol and improves the nutritive value of full-fat rapeseed in chickens
}

\author{
D. Józefiak ${ }^{1,5}$, A. Ptak ${ }^{2}$, S. Kaczmarek1, P. Maćkowiak ${ }^{3}$ \\ and R.M. Engberg ${ }^{4}$
}

\author{
Poznan University of Life Sciences, \\ 'Department of Animal Nutrition and Feed Management, \\ 'Department of Animal Physiology and Biochemistry \\ Wotynska 33, 60-637 Poznań, Poland \\ ${ }^{3}$ Piast Group Research and Development Center \\ Lewkowiec 50, 63-400 Ostrów Wlkp., Poland \\ 'Aarhus University, Faculty of Agricultural Sciences, \\ Department of Animal Health and Bioscience \\ PO Box 50, DK-8830 Tjele, Denmark
}

(Received 12 August 2010; revised version 3 January 2011; accepted 12 March 2011)

\begin{abstract}
Two 42-d floor pen studies of identical design were conducted to cvaluate the efficacy of enzyme supplementation of broiler diets containing full-fat double zero rapeseed. In both trials, 300 1-d-old Ross 308 males were allocated randomly to two dictary treatments with 15 replicates ( 10 birds per replicate). The birds received two isonutritive diets, pelleted at $78^{\circ} \mathrm{C}$. Dicts were either not supplemented or supplemented with a commercial enzyme blend providing xylanase and $\beta$-glucanase. In general, in both trials the supplementation of carbohydrase improved bird performance, however, only in the second experiment the overall body weight gain and feed conversion ratio were significantly improved. The enzyme addition reduced $(\mathrm{P}<0.05)$ the concentration of serum insulin $(0.75 \mathrm{vs} 0.49 \mathrm{ng} / \mathrm{ml})$, total cholesterol $(4.35 \mathrm{vs} 3.03 \mathrm{mmol} / \mathrm{l})$ and its fractions, whereas no effect on the concentration of blood glucose was observed. No significant effect of the enzymes on the ileal digestibility of nutrients or on apparent ileal metabolizable energy was found; however, total tract fat digestibility and AMEn value tended to be higher following enzyme supplementation. (78.2 vs $73.8 \%$ and 12.6 vs $12.4 \mathrm{MJ} / \mathrm{kg}$ ).

The results of the present study suggest that carbohydrases supplementation may improve the nutritive value of full-fat rapeseed in broiler chicken diets.
\end{abstract}

\footnotetext{
${ }^{5}$ Corresponding author: c-mail: damjo@up.poznan.pl
} 
KEY WORDS: full-fat rapeseed, enzyme, insulin, glucose, broiler

\section{INTRODUCTION}

In countries depending on soyabean meal import, rapeseed by-products (i.e. meal, cake) are commonly used as alternative protein source in poultry nutrition (Nguyen et al., 2003; Gordon et al., 2004, Smulikowska et al., 2006). However, limited information is available about the nutritive value of full-fat seeds for broiler chickens.

Full-fat rapeseed is a valuable source of energy, n-3 fatty acids and protein for poultry (Meng et al., 2006). On the other hand it is well documented that its nutritional value is limited due to the presence of glucosinolates, non-starch polysaccharides (NSP) and phytates (Nguyen et al., 2003; Smulikowska et al., 2006). It has also been demonstrated that coarse grinding of rapeseed impairs the digestibilitiy of nutrients and the apparent metabolizable energy (AME) content (Meng et al., 2006). Some authors suggest that after mechanical disruption of the cell walls, full-fat rapeseed can be used in broiler chicken nutrition without negative effects at concentrations of up to $15 \%$ (Gordon et al., 2004). However, other studies show that even after fine grinding, the AME content of full-fat rapeseed may vary due to oil-encapsulation by cell wall polysaccharides (Meng et al., 2006). Thus, it is suggested that the use of appropriate exogenous carbohydrate hydrolysing enzymes could improve fat availability and hence increase the use of full-fat rapeseed for broiler chickens.

In recent years, much information has been published considering the mode of action of carbohydrases in poultry nutrition, showing a wide range of positive effects, among others the improvement of nutrient utilization through a reduction of the gut microflora activity competing with the host for available nutrients and a positive modulation of immune functions (Józefiak et al., 2004; Meng et al., 2006; Gao et al., 2007). However, relatively little research has been conducted on the possible effects of exogenous enzymes on fat and carbohydrate metabolism, and the concentration of blood metabolites or hormones. The aim of the present study was to investigate the effects of carbohydrase enzymes on growth performance, nutrient digestibility, blood cholesterol, glucose and insulin concentrations in broiler chickens fed diets with full-fat rapeseeds.

\section{MATERIAL AND METHODS}

\section{Study design and animals}

Two feeding trials with the same experimental design, but differing with regard to the composition of the experimental diets (Tables 1 and 2), were conducted. 
Table 1. Composition, calculated and analysed values of the non-supplemented diets in the first trial

\begin{tabular}{|c|c|c|c|}
\hline \multirow{2}{*}{ Item } & \multicolumn{3}{|c|}{ Diets, period of fecding } \\
\hline & starter $(0-9 d)$ & grower $(10-27 \mathrm{~d})$ & finisher $(28-42 \mathrm{~d})$ \\
\hline \multicolumn{4}{|l|}{ Ingredients, $\mathrm{g} / \mathrm{kg}$} \\
\hline wheat & 214.8 & 244.7 & 222.0 \\
\hline triticale & 50.0 & 50.0 & 95.0 \\
\hline soyabean meal & 303.7 & 234.3 & 175.0 \\
\hline maize & 350.0 & 350.0 & 350.0 \\
\hline rapeseed 00 (full-fat) & 30.0 & 80.0 & 120.0 \\
\hline monocalcium phosphate & 14.0 & 10.5 & 7.5 \\
\hline lard & 14.1 & 8.0 & 7.0 \\
\hline limestone & 11.4 & 9.9 & 7.8 \\
\hline alimet MHA (liquid) & 2.8 & 2.7 & 2.7 \\
\hline $\mathrm{NaCl}$ & 3.0 & 3.0 & 3.0 \\
\hline L-lysine-HCl & 2.4 & 3.1 & 3.0 \\
\hline $\mathrm{Na}_{2} \mathrm{CO}_{3}$ & 0.5 & 0.5 & 0.5 \\
\hline L-threonine & 0.3 & 0.3 & 0.5 \\
\hline mineral and vitamin premix ${ }^{1}$ & 3.0 & 3.0 & 3.0 \\
\hline $\mathrm{TiO}_{2}$ & - & - & 3.0 \\
\hline \multicolumn{4}{|l|}{ Calculated } \\
\hline $\mathrm{AME}, \mathrm{MJ} / \mathrm{kg}$ & 12.15 & 12.45 & 12.65 \\
\hline \multicolumn{4}{|l|}{ Analysed } \\
\hline crude protein, $\mathrm{g} / \mathrm{kg}$ & 217.2 & 196.0 & 179.0 \\
\hline crude fat, $\mathrm{g} / \mathrm{kg}$ & 49.0 & 67.0 & 74.5 \\
\hline In vitro viscosity, $\mathrm{mPas} \cdot \mathrm{s}$ & 18.8 & 22.1 & 24.1 \\
\hline $\begin{array}{l}1 \text { mineral and vitamin premix pr } \\
80, \text { menadione } 2.50, \text { vit. } \mathrm{B}_{12}\end{array}$ & $\begin{array}{l}\text { es per kg diet: } \\
\text { olic acid } 1.17 \\
\text {-biotin } 0.18 \text {, } \\
\text { mycin } 60\end{array}$ & $\begin{array}{l}\text { A } 11166 \text {, cholec } \\
\text { he } 379, \mathrm{D} \text {-pantoth } \\
\text { sine } 4.0 \text {, ethoxyqu }\end{array}$ & $\begin{array}{l}\text { rol } 2500 ; \mathrm{mg} \text { : vit. } \\
\text { acid } 12.5 \text {, riboflavi } \\
.09, \mathrm{Mn} 73, \mathrm{Zn} 55\end{array}$ \\
\hline
\end{tabular}

The first preliminary trial was focused on growth performance and ileal digestibility of crude protein, fat and apparent metabolizable energy content. In the second experiment, growth performance as well as the concentration of glucose, cholesterol fractions and insulin in blood were also measured. Both experiments were conducted in 30 floor pens placed within a commercial chicks house to simulate commercial conditions regarding stocking density, health and hygiene. In each trial a total of 300 one-day-old male broiler chicks (Ross 308) were allocated randomly to 2 dietary treatments (15 replicates of 10 birds per pen) in a random block design. In both trials, broilers received the experimental diets (Tables 1 and 2, respectively), which were provided without or with supplementation of exogenous enzyme preparations as described below. The lighting programme was as follows: during the first week $23 \mathrm{~h}$ of light and $1 \mathrm{~h}$ dark, from day 7 to day $21,19 \mathrm{~h}$ light and $5 \mathrm{~h}$ dark, and from day 22 to day 42 , $23 \mathrm{~h}$ light and $1 \mathrm{~h}$ dark. 
The experiment complied with the guidelines of the Local Ethic Commission with respect to animal experimentation and care of animals under study.

Table 2. Composition, calculated and analysed values of the non-supplemented diets in the second trial

\begin{tabular}{|c|c|c|c|}
\hline \multirow{3}{*}{ Item } & \multicolumn{3}{|c|}{ Diets, period of feeding } \\
\hline & starter & grower & finisher \\
\hline & $0-9 \mathrm{~d}$ & $10-27 \mathrm{~d}$ & $28-42 \mathrm{~d}$ \\
\hline \multicolumn{4}{|l|}{ Ingredients, $\mathrm{g} / \mathrm{kg}$} \\
\hline wheat & 260.4 & 298.0 & 320.9 \\
\hline soyabean meal & 307.5 & 231.6 & 174.2 \\
\hline maize & 350.0 & 350.0 & 350.0 \\
\hline rapeseed 00 (full-fat) & 30.0 & 80.0 & 120.0 \\
\hline monocalcium phosphate & 14.1 & 10.2 & 7.3 \\
\hline lard & 14.4 & 8.4 & 7.4 \\
\hline limestone & 11.4 & 9.1 & 7.8 \\
\hline alimet MHA (liquid) & 2.7 & 2.7 & 2.5 \\
\hline $\mathrm{NaCl}$ & 3.3 & 3.0 & 2.8 \\
\hline L-lysine- $\mathrm{HCl}$ & 2.4 & 3.1 & 3.3 \\
\hline $\mathrm{Na}_{2} \mathrm{CO}_{3}$ & 0.5 & 0.5 & 0.5 \\
\hline L-threonine & 0.3 & 0.4 & 0.3 \\
\hline mineral and vitamin premix ${ }^{1}$ & 3.0 & 3.0 & 3.0 \\
\hline \multicolumn{4}{|l|}{ Calculated } \\
\hline $\mathrm{AME}, \mathrm{MJ} / \mathrm{kg}$ & 12.15 & 12.45 & 12.65 \\
\hline \multicolumn{4}{|l|}{ Analysed } \\
\hline crude protein, $\mathrm{g} / \mathrm{kg}$ & 216.0 & 194.5 & 181.0 \\
\hline crude fat, $\mathrm{g} / \mathrm{kg}$ & 48.5 & 63.0 & 73.0 \\
\hline In vitro viscosity $\mathrm{mPas} \cdot \mathrm{s}$ & 18.1 & 19.0 & 19.4 \\
\hline
\end{tabular}

\section{Feeding programme and diets}

The composition of the diets and feeding periods are presented in Tables 1 and 2. The diets contained an ionophore coccidiostat (salinomycin, $60 \mathrm{mg} / \mathrm{kg}$ feed). The full-fat rapeseed was ground using a roller mill, to obtain an average mash particle size below $0.55 \mathrm{~mm}$. The experimental diets were supplemented on top before pelleting with $250 \mathrm{mg} / \mathrm{kg}$ of Ronozyme ${ }^{\circledR}$ WX and $150 \mathrm{mg} / \mathrm{kg}$ of Ronozyme ${ }^{\circledR} \mathrm{VP}$, supplied by DSM Nutritional Products (Poland) and providing E1607 endo-1,4 $\beta$-xylanase EC 3.2.1.8, $250 \mathrm{FXU}$ and E1603 endo-1,3(4)- $\beta$-glucanase EC 3.2.1.6, 7.5 FBG per $\mathrm{kg}$ of the diet. The concentrations of enzymes are given according to producers declaration. All diets were pelleted at $78^{\circ} \mathrm{C}$, in a double conditioning system with 2 min retention time, and were offered ad libitum. To calculate protein and fat digestibility as well as AMEn content, the diets used in experiment 1 , were supplemented with titanium dioxide $(3.0 \mathrm{~g} / \mathrm{kg})$ from $\mathrm{d} 28$ to $\mathrm{d} 42$. 


\section{Sample collection}

On days 10, 28 and 42, the birds and feed refusals were weighed and the feed intake, body weight gain and feed conversion ratio were calculated. In the first trial, at $42^{\text {th }}$ day excreta samples from all pens from each treatment were collected and pooled into 5 replicate samples of approximately $60 \mathrm{~g}$ each. The same day from each treatment 50 randomly selected birds were killed by cervical dislocation and the ileum was removed. Digesta were flushed from the terminal ileum $(15 \mathrm{~cm}$, adjacent to the ileo-caecal junction) and pooled by cage ( $5 \mathrm{birds} /$ sample) to provide sufficient material for chemical analysis $(n=10)$. The digesta samples were immediately frozen on dry ice, freeze-dried and ground before further analyses. In the second trial, before blood collection all birds were fed for $3 \mathrm{~h}$. Blood samples from randomly chosen broiler chickens $(n=10)$ were collected by puncture of the wing vein at days 30,36 and 42 .

\section{Chemical analyses}

Feed samples were analysed in duplicate for crude protein, crude fat, using AOAC (2005) methods 976.05 and 920.39 , respectively. For all chemical analysis, samples were ground to pass through a $0.5 \mathrm{~mm}$ sieve. The viscosity of the nonsupplemented diets was measured as described by Józefiak et al. (2004). Titanium dioxide was determined according to Short et al. (1996), the samples were prepared according to the procedure proposed by Myers et al. (2004). Gross energy was determined using an adiabatic bomb calorimeter (KL 12Mn, Precyzja-Bit PPHU, Poland) standardized with benzoic acid. Nitrogen content was analysed by the Kjel Foss Automatic 16210 (A/S N. Foss Electric, Denmark). Fat content was determined using the Soxtec System HT 1043, Extraction Unit (Foss Tecator, Denmark).

Glucose in whole blood was measured according to Datar et al. (2006). At the end of the trial ( $42 \mathrm{~d}$ ), the same procedure of sampling was done to estimate serum concentration of insulin and cholesterol fractions. Serum was obtained by centrifugation at $1000 \mathrm{~g}$ for $10 \mathrm{~min}$ and stored at $-20^{\circ} \mathrm{C}$ until analysis. Insulin concentrations were determined using the radioimmunoassay method described by Geraert et al. (1996). A calibration curve was made using serial dilutions of chicken insulin between 0 and $5 \mathrm{ng} / \mathrm{ml}$. The results were plotted on a semilogarithmic scale. For measuring counts per min, a rat insulin RIA kit was used (Insulin RIA Kit; Linco Rescarch, Inc., USA) as described by Morgan and Lazarow (1963). Cholesterol was assayed using the method described by Richmond (1973).

\section{Calculations and statistical analysis}

In experiment 1 the ileal and total tract apparent protein and fat and digestibility 
AME value of diets were calculated relative to the ratio of $\mathrm{TiO}_{2}$ to the content of the nutrient in question of gross energy in the feed or digesta (excreta). Total tract AMEn was corrected to zero nitrogen balance using $34.4 \mathrm{~kJ} / \mathrm{g} \mathrm{N}$ retained (Hill and Anderson, 1958)

Statistical analysis of results was performed using the GLM procedure of the SAS software (SAS, 1990). Differences between groups and their significance were evaluated by Student's $t$-test. Data are presented as means with pooled standard error (SEM).

\section{RESULTS}

In both trials birds were healthy and throughout the experiments no mortality occurred. The effects of dietary enzyme supplementation on growth performance, digestibility, blood glucose, serum cholesterol and insulin concentrations are summarized in Tables 3 and 4 . In the first trial, carbohydrase

Table 3. Effect of dietary enzyme supplementation on growth performance, ileal digestibility, apparent ileal (AME) and total tract (AMEn) metabolizable energy value. Experiment 1

\begin{tabular}{|c|c|c|c|c|}
\hline Item & No enzyme & Enzyme $^{\prime}$ & SEM & Probability \\
\hline \multicolumn{5}{|l|}{ Body weight gain, $g^{2}$} \\
\hline $0-9 \mathrm{~d}$ & 196 & 215 & 2.49 & $<0.0001$ \\
\hline $10-27 d$ & 1240 & 1238 & 7.51 & 0.934 \\
\hline $28-42 d$ & 1275 & 1257 & 22.9 & 0.714 \\
\hline $0-42 d$ & 2711 & 2712 & 26.7 & 0.991 \\
\hline \multicolumn{5}{|l|}{ Feed intake, $g^{2}$} \\
\hline $0-9 d$ & 250 & 252 & 2.35 & 0.607 \\
\hline $10-27 d$ & 1847 & 1872 & 9.47 & 0.216 \\
\hline $28-42 d$ & 2309 & 2263 & 22.8 & 0.332 \\
\hline $0-42 \mathrm{~d}$ & 4406 & 4387 & 30.2 & 0.760 \\
\hline \multicolumn{5}{|c|}{ Feed conversion ratio, $\mathrm{g} / \mathrm{g}^{2}$} \\
\hline $0-9 d$ & 1.27 & 1.17 & 0.013 & $<0.0001$ \\
\hline $10-27 d$ & 1.49 & 1.51 & 0.008 & 0.244 \\
\hline $28-42 d$ & 1.82 & 1.80 & 0.028 & 0.791 \\
\hline $0-42 \mathrm{~d}$ & 1.63 & 1.62 & 0.013 & 0.809 \\
\hline \multicolumn{5}{|c|}{ Ileal digestibility at $42 d, \%$} \\
\hline crude protein ${ }^{3}$ & 77.9 & $78.0^{5}$ & 1.32 & 0.334 \\
\hline crude fat ${ }^{3}$ & 73.8 & 78.2 & 7.01 & 0.344 \\
\hline \multicolumn{5}{|c|}{ Metabolizable energy at $42 \mathrm{~d}, \mathrm{MJ} / \mathrm{kg}^{2}$} \\
\hline ileal $\mathrm{AME}^{3}$ & 11.9 & 12.4 & 0.305 & 0.398 \\
\hline total tract AMEn ${ }^{4}$ & 12.4 & 12.6 & 0.122 & 0.631 \\
\hline
\end{tabular}

${ }^{1}$ sec Material and Methods; ${ }^{2}$ means represent 15 pens of 10 chicks each, $n=15 ;{ }^{3}$ means represent 10 pooled samples of 5 chicks each; ${ }^{4}$ means represent 5 pooled samples of 30 chicks each; SEM - pooled standard crror 
Table 4. Effect of dietary enzyme supplementation on growth performance, concentration of glucose in blood, and cholesterol and insulin in scrum at 42 day of life. Experiment 2

\begin{tabular}{|c|c|c|c|c|}
\hline Item & No enzyme & Enzyme $^{1}$ & SEM & Probability \\
\hline \multicolumn{5}{|l|}{ Body weight gain, $g^{2}$} \\
\hline $0-9 d$ & $215^{4}$ & 216 & 1.48 & 0.804 \\
\hline $10-27 d$ & 1185 & 1220 & 7.88 & 0.048 \\
\hline $28-42 d$ & 1442 & 1529 & 7.90 & 0.003 \\
\hline $0-42 d$ & 2842 & 2965 & 17.9 & 0.001 \\
\hline \multicolumn{5}{|l|}{ Feed intake, $g^{2}$} \\
\hline $0-9 d$ & 288 & 297 & 2.83 & 0.100 \\
\hline $10-27 d$ & 1896 & 1905 & 10.55 & 0.683 \\
\hline $28-42 d$ & 3072 & 3028 & 28.99 & 0.413 \\
\hline $0-42 \mathrm{~d}$ & 5256 & 5229 & 32.65 & 0.691 \\
\hline \multicolumn{5}{|c|}{ Feed conversion ratio, $\mathrm{kg} / \mathrm{kg} \mathrm{BWG}{ }^{2}$} \\
\hline $0-9 \mathrm{~d}$ & 1.34 & 1.38 & 0.015 & 0.198 \\
\hline $10-27 d$ & 1.60 & 1.56 & 0.009 & 0.047 \\
\hline $28-42 \mathrm{~d}$ & 2.14 & 1.98 & 0.070 & $<0.0001$ \\
\hline $0-42 d$ & 1.85 & 1.77 & 0.010 & $<0.0001$ \\
\hline \multicolumn{5}{|c|}{ Cholesterol at $42 d, \mathrm{mmoll}^{3}$} \\
\hline total & 4.35 & 3.03 & 0.197 & $<0.001$ \\
\hline free & 2.30 & 1.48 & 0.118 & $<0.001$ \\
\hline esterified & 2.05 & 1.55 & 0.091 & 0.003 \\
\hline Insulin at $42 \mathrm{~d}, \mathrm{ng} / \mathrm{ml}^{3}$ & 0.75 & 0.49 & 0.037 & 0.057 \\
\hline \multicolumn{5}{|l|}{ Glucose, $\mathrm{mg} / \mathrm{dl}^{3}$} \\
\hline $30 \mathrm{~d}$ & 208 & 201 & 3.34 & 0.328 \\
\hline $36 \mathrm{~d}$ & 213 & 213 & 3.63 & 0.968 \\
\hline $42 \mathrm{~d}$ & 250 & 237 & 3.76 & 0.113 \\
\hline
\end{tabular}

${ }^{1}$ sec Material and Methods; ${ }^{2}$ means represent 15 pens of 10 chicks each, $n=15 ;{ }^{3} \mathrm{n}=10$;

SEM - pooled standard error

supplementation increased body weight gain $(\mathrm{BWG})(\mathrm{P}<0.001)$ only in the starter phase $(0-9 \mathrm{~d})$. In the second trial, the BWG of broiler chickens fed diets supplemented with enzymes was higher from: 10-27, $(\mathrm{P}<0.05), 28-42$ days, $(\mathrm{P}<0.01)$ and in the entire trial $(\mathrm{P}<0.001)$. The feed conversion ratio was improved in the first trial only in the starter phase $(\mathrm{P}<0.001)$ and in the second trial in the period from $10-27 \mathrm{~d}(\mathrm{P}<0.05)$ and from $28-42 \mathrm{~d}(\mathrm{P}<0.001)$. In both trials, no effects of enzyme supplementation on feed intake were observed.

The ileal fat digestibility of birds fed the enzyme supplemented diet tended to be higher than that of non-supplemented birds (78.2 vs $73.8 \%)$ and the effect of enzyme supplementation on ileal protein digestibility, ileal energy and total tract AMEn was not significant. The incorporation of the enzymes into diets lowered serum insulin $(\mathrm{P}>0.05)$, as well as total cholesterol $(\mathrm{P}<0.001)$ both in the free $(\mathrm{P}<0.001)$ and esterified $(\mathrm{P}<0.01)$ form, but had no effect on blood glucose level (Table 4). 


\section{DISCUSSION}

In general, in both trials the carbohydrase supplementation improved broiler performance, however, only in the second experiment the final BWG and feed conversion ratio (FCR) were significantly better $(\mathrm{P}<0.05)$ at 42 days. Nguyen et al. (2003) showed that an inclusion of $10 \%$ of full-fat rapeseed in a diet supplemented with xylanase did not impair broiler chicken performance as compared to a control diet formulated without rapeseed. Gordon et al. (2004) used full-fat rapeseed in a range of 0 to $16 \%$, without enzyme supplementation and found that the body weight of males was reduced at $42 \mathrm{~d}$ of life and that of females already at $14 \mathrm{~d}$ of life. However, similarly to our trial $10 \%$ of full-fat rapeseed had no adverse effects on BWG or FCR. The results of the present trial and the data from other authors suggest that the nutritional value of full-fat rapeseed in feed formulations for broiler chicken can be improved by carbohydrases supplementation when this raw material is used up to $12 \%$. It is also suggested that more investigations should be carried out to estimate the effect of grinding and pelleting procedures. In the studies of Summers et al. (1982), Nguyen et al. (2003) and Gordon et al. (2004), the size of the particles was not described. In the present experiment the rape seeds were ground on roller-mill to obtain a particle size of $0.55 \mathrm{~mm}$. However, after incorporation into the diet, the diets were pelleted and this process is known to reduce particle size (Engberg et al., 2002).

Similarly to mammals, blood cholesterol in birds could be affected by different dietary factors, including exogenous enzymes. After supplementing a rye-based diet with a $\beta$-glucanase and xylanase preparation, Frigård et al. (1994) found a $37 \%$ increase in serum cholesterol in broilers. In contrast in the present study, carbohydrases decreased total cholesterol approximately by $30 \%$; its free fraction by $36 \%$ and its esterified fraction by $24 \%$. The cholesterol reducing effect of soluble dietary fibre fractions of diet is well known and is taken advantage of in human nutrition. In broiler chickens, viscous diets containing water-soluble fibre have anti-nutritional effects thus impairing bird performance. The antinutritional effect of high intestinal viscosity is supposed to be partly linked to an increased growth of intestinal bacteria capable of bile acid deconjugation, thus impairing the absorption of fat (Knarreborg et al., 2004). The addition of NSP degrading enzymes to feed containing high amounts of water soluble carbohydrates, has been shown to specifically improve fat digestibility (Silva and Smithard, 2002) and to increase plasma concentrations of cholesterol (Frigard et al., 1994). In the present study, the main dietary cereals used were maize and wheat, thus the measured in vitro viscosities of the diets were relatively low (Tables 1 and 2). Therefore, it is suggested that lower cholesterol levels after enzyme supplementation were probably not directly linked to intestinal viscosity but rather to dietary fat 
composition and absorption. Meng et al. (2006) demonstrated that carbohydrase supplementation of a diet with canola seeds resulted in an improved feed:gain ratio and improved fat digestibility and AMEn content. The authors suggested that the energy availability after enzyme supplementation was directly related to improved fat digestibility $\left(\mathrm{r}^{2}=0.94 ; \mathrm{P}<0.0001\right)$. In the present study, the fat digestion $(73.8 \mathrm{vs}$ $78.2 \%)$ as well as the ileal apparent energy value (11.9 vs 12.4$)$ were numerically improved after enzyme addition $(\mathrm{P}>0.05)$. Additionally, in both trials a better feed utilization was observed in different growth phases $(\mathrm{P}<0.05)$. Therefore, it is suggested that similar to mammals, the changes in the serum cholesterol of broiler chickens in the present trial could be linked to an increased absorption of unsaturated fatty acids from full-fat rapeseed. This statement could be supported by the findings of Newman et al. (2005), who fed broiler chickens with diets containing different sources of saturated and polyunsaturated fatty acids. The diets rich in n-3 and n-6 acids showed similar effects to our study. Insulin in birds and other species is related to the insulin-like growth factors (IGF-1 and IGF-2) which are a family of polypeptide hormones associated with many metabolic and anabolic properties affecting performance (Gao et al., 2007). In the present study, no hyperglycaemia was observed after insulin drop due to enzyme addition. The level of the insulin was in the range observed by other authors (Crespo and EsteveGarcia, 2003), however its decrease after enzyme supplementation was very drastic $(\mathbf{P}<0.05)$. Simultaneously, the lowered insulin/glucose molar ratio observed after addition of enzymes to the diet may indicate that it could increase the sensitivity of target tissues to insulin, especially considering better feed conversion ratio in enzyme supplemented groups. In mammals, the fatty acid profile affects insulin secretion and insulin resistance (Storlien et al., 2000). In broiler chickens, Crespo and Esteve-Garcia (2003) observed that inclusion of sunflower or linseed oil resulted in lower levels of insulin and cholesterol as compared to the addition of tallow or olive oil $(\mathrm{P}<0.05)$. The authors suggested that higher insulin levels in broilers fed diets rich in saturated fatty acids could be related to higher fat deposition. A similar correlation may be present in the current trial; specifically that feeding polyunsaturated fatty acid (PUFA) by Crespo and Esteve-Garcia (2003) also did not trigger blood glucose. Broilers fed either with tallow, fish oil or sunflower oil being rich in saturated fatty acid, n-3 PUFA and n-6 PUFA, respectively, had higher plasma insulin concentration when fed the diet containing tallow. This phenomenon is associated with the different structure of saturated and unsaturated acids, particularly the presence of palmitate and stearate in tallow, which increases the insulin release (Newman et al., 2005). Hypocholesterolaemic and insulinotropic effects of dictary fats are well documented in mammalian species (Storlien et al., 2000). The results from the present trial as well as other studies (Crespo and Esteve-Garcia, 2003; Newman et al., 2005) indicate that this 
mode of action is not confined to mammals. To which extent the observed effects of the applied enzymes on blood insulin as well as on cholesterol do play a role in broiler growth needs further investigations.

The present study suggests that full-fat rapeseed can be used effectively in broiler chicken diets. The addition of carbohydrases may facilitate the nutrient accessibility for digestion and thus enhance the feeding value of feed mixtures with full-fat rapeseed for broilers.

\section{REFERENCES}

AOAC, 2005. Association of Official Analytical Chemists, Official Methods of Analysis. $18^{\text {th }}$ Edition. Arlington, VA

Crespo N., Esteve-Garcia E., 2003. Polyunsaturated fatty acids reduce insulin and very low density lipoprotein levels in broiler chickens. Poultry Sci. 82, 1134-1139

Datar S.P., Suryavanshi D.S., Bhonde R.R., 2006. Chick pancreatic B islets as an alternative in vitro model for screening insulin secretagogues. Poultry Sci. 85, 2260-2264

Engberg R.M., Hedemann M.S., Jensen B.B., 2002. The influence of grinding and pelleting of feed on the microbial composition and activity in the digestive tract of broiler chickens. Brit. Poultry Sci. $43,569-579$

Frigård T., Pettersson D., Aman P., 1994. Fiber-degrading enzyme increases body weight and total serum cholesterol in broiler chickens fed a rye-based diet. J. Nutr. 124, 2422-2430

Gao F., Jiang Y., Zhou G., Han Z., 2007. The effects of xylanase supplementation on growth, digestion, circulating hormone and metabolite levels, immunity and gut microflora in cockerels fed on wheat-based dicts. Brit. Poultry Sci. 48, 480-488

Geraert P.A., Padilha J.C.F., Guillaumin S., 1996. Metabolic and endocrine changes induced by chronic heatexposure in broiler chickens : biological and endocrinological variables. Brit. J. Nutr. $75,205-216$

Gordon S.H., Short F., Wilson D.W., Croxall R., 2004. The effect of dietary concentration of rapeseed meal or whole rapeseed on broiler performance and litter quality. Brit. Poultry Sci. 45, $21-22$

Hill F.W., Anderson D.L., 1958. Comparison of metabolizable energy and productive energy determinations with growing chicks. J. Nutr. 64, 587-603

Józefiak D., Rutkowski A., Frątczak M., Boros D., 2004. The effect of dietary fibre fractions from different cereals and microbial enzyme supplementation on performance, ileal viscosity and short-chain fatty acid concentrations in the caeca of broiler chickens. J. Anim. Feed Sci. 13, $487-496$

Knarreborg A., Lauridsen C., Engberg R.M., Jensen S.K., 2004. Dietary antibiotic growth promoters enhance the bioavailability of alpha-tocopheryl acetate in broilers by altering lipid absorption. J. Nutr. 134, 1487-1492

Meng X., Slominski B., Campbell L., Guenter W., Jones O., 2006. The use of enzyme technology for improved energy utilization from full-fat oilseeds. Part I: canola seed. Poultry Sci. 85, 1025 1030

Morgan C.R., Lazarow A., 1963. Immunoassay of insulin: Two antibody system. Plasma insulin levels in normal, subdiabetic, and diabetic rats. Diabetes 12, 115-126

Myers W.D., Ludden P.A., Nayigihugu V., Hess B.W., 2004. Technical Note: A procedure for the preparation and quantitative analysis of samples for titanium dioxide. J. Anim. Sci. 82, 179183 
Newman R., Bryden W., Kirby A., Storlien L., Downing J., 2005. Dietary n-3 and n-6 fatty acids alter avian glucose metabolism. Brit. Poultry Sci. 46, 104-113

Nguyen C.V., Smulikowska S., Mieczkowska A., 2003. Effect of linseed and rapeseed or linseed and rapesecd oil on performance, slaughter yield and fatty acid deposition in edible parts of the carcass in broiler chickens. J. Anim. Feed Sci. 12, 271-288

Richmond W., 1973. Preparation and properties of a cholesterol oxidase from Nocardia sp. and Its application to the enzymatic assay of total cholesterol in serum. Clin. Chem. 19, 13501356

SAS, 1990. SAS User's Guide: Statistics. Version 6. SAS Institute. Cary, NC

Short F.J., Gorton P., Wiscman J., Boorman K.N., 1996. Determination of titanium dioxide added as an incrt marker in chicken digestibility studies. Anim. Feed Sci. Tech. 59, 215-221

Silva S.S., Smithard R.R., 2002. Effect of enzyme supplementation of a rye-based diet on xylanase activity in the small intestine of broilers, on intestinal crypt cell proliferation and on nutrient digestibility and growth performance of the birds. Brit. Poultry Sci. 43, 274-282

Smulikowska S., Mieczkowska A., Czerwiński J., Weremko D., Nguyen C.V., 2006. Effects of exogenous phytase in chickens fed diets with differently processed rapeseed expeller cakes. J. Anim. Feed Sci. 15, 237-252

Storlien L.H., Higgins J.A., Thomas T.C., Brown M.A., Wang H.Q., Huang X.F., Else P.L., 2000. Diet composition and insulin action in animal models. Brit. J. Nutr. 83, Suppl. I, S85-S90

Summers J.D., Shen H., Leeson S., 1982. The value of the canola seed in poultry diets. Can. J. Anim. Sci. $62,861-868$ 